Review article

\title{
Real-life experiences of patients with Parkinson's disease
}

\author{
Martina Tomagová *, Martina Lepiešová, Ivana Bóriková, Juraj Čáp, Jana Nemcová, \\ Mária Zanovitová \\ Comenius University in Bratislava, Jessenius Faculty of Medicine in Martin, Department of Nursing, Martin, Slovak Republic
}

\begin{abstract}
Parkinson's disease (PD) has a major impact on patients' real-life experience. Up to now, there has been a lack of literature reviews, including comprehensive systematic ones oriented on the real life experience of PD patients. The aim was to identify, analyse, summarise and synthesise findings from qualitative studies focused on real-life experiences of PD patients. A qualitative literature review was adopted. Using EBSCOhost interface, the following research databases were searched in January 2018: Academic Search Complete; Health Source: Nursing/Academic Edition and MEDLINE. To appraise the methodological quality of selected studies, the CASP - Qualitative Research Checklist was used. Thematic synthesis was adopted to synthesise qualitative findings. From the 241 records retrieved, 16 studies were relevant to the aim of our review. Six main themes were generated by thematic synthesis: Changing body; Range of emotional responses; Changing identity, self-worth and purpose; Social life limitations and challenges; Life control; and Future perspectives. The review presents a broader perspective on how PD patients experience their life with the disease. The findings may be helpful for healthcare professionals in order to better understand the need to implement individualized patient-centred care. Our findings may be useful to guide further qualitative research on the issue of the life experience of PD patients as well as to conduct systematic review.
\end{abstract}

Keywords: Life experience; Narrative review; Patient with Parkinson's disease; Qualitative studies; Thematic synthesis

\section{Introduction}

Parkinson's disease (PD) is the second most common neurodegenerative condition in the world (Pringsheim et al., 2014). It is a neurological disorder with evolving layers of complexity (Kalia and Lang, 2015). Current pharmacological and surgical treatments are aimed at symptom management and slowing disease progress (Liddle et al., 2018). PD is stressful for patients since they experience changes in physical mobility and general independence, which have an impact on social activities, work, and relationships (Rod et al., 2013). The divergence between PD's clinical priorities to alleviate motor symptomatology and patients' own concerns draws our attention to the need for lived experience research (Gibson and Kierans, 2017). According to Smith et al. (2012), experience is a complex concept and we should be especially interested in what happens when the everyday flow of lived experience takes on a particular significance for people. This usually occurs when something important has happened in our lives. Understanding and analysing real-life human experience is a focus of qualitative studies (Korstjens and Moser, 2017; Stern et al., 2014). There are several qualitative studies concerning the lived experience of patients with PD, with a narrowed focus on experiencing unpredictability (Redmond and Suddick, 2012), uncertainty (Eccles et al., 2011), loss of control (Gibson, 2016), stigma (Naz- zal and Khalil, 2017), fear of falling (Jonasson et al., 2018), social withdrawal and social isolation (Sunvisson and Ekman, 2001), or experiencing PD symptoms such as freezing (Redmond and Suddick, 2012), dysphagia (Miller et al., 2006), constipation (McClurg et al., 2016) or sleep disturbance (Suddick and Chambers, 2010). But up to now there has been a lack of literature reviews, including systematic ones oriented on the issue of the lived experience of patients with PD in general.

\begin{abstract}
Aim
The aim of this qualitative literature review was to identify, analyse, summarise and synthesize findings from qualitative studies concentrated on the real-life experience of patients with PD. The review question was determined: How do patients with PD experience their life?
\end{abstract}

\section{Materials and methods}

\section{Study design}

A qualitative literature (narrative) review was adopted in this study.

A literature review of evidence generated through qualitative studies was undertaken with the use of the PRISMA Statement to enhance the clarity and transparency of its conduct and reporting (Moher et al., 2009). A variety of mnemonics exist to

\footnotetext{
* Author for correspondence: Martina Tomagová, Comenius University in Bratislava, Jessenius Faculty of Medicine in Martin, Department of Nursing, Malá Hora 5, 03601 Martin, Slovak Republic; e-mail: tomagova@jfmed.uniba.sk http://doi.org/10.32725/kont.2019.036 
help structure the review question and to guide the searching of the literature. In our case, the PICo (Population-phenomenon of Interest-Context) was chosen as one of those useful for qualitative reviews (Korstjens and Moser, 2017). To appraise the methodological quality and the strength of multiple selected studies, they were systematically assessed with the use of a critical appraisal tool by the Critical Appraisal Skills Programme CASP - Qualitative Research Checklist (Critical Appraisal Skills Programme, 2018). As a method for synthesis of qualitative findings, the thematic synthesis by Thomas and Harden (2008) was adopted.

\section{Sources}

To identify publications relevant to the aim of this review, the following research databases within EBSCOhost interface were searched: Academic Search Complete; Health Source: Nursing/ Academic Edition and MEDLINE.

\section{Search method}

Searching of the literature was conducted in January 2018. The search terms were as follows: a patient, Parkinson for population (P); experience, lived experience, life experience for phenomenon of interest (I); and qualitative, phenomenology for context (Co).

\section{Eligibility criteria}

Several inclusion and exclusion criteria were chosen to select eligible studies. We included full-text articles, published in English language in peer-reviewed journals with no time limits of publication. Qualitative studies of any design concentrated on the experience of patients with PD from the patient's perspective were included, regardless of the sample size, gender of the patient or stage of the disease. We excluded studies concerning the perspectives of healthcare providers, informal caregivers or family members, and other publication types, e.g. conference papers, abstracts, articles published in non-peerreviewed journals, review articles, book chapters, theoretical analysis of the problem, editorials, book reviews, or dissertations.

\section{Study selection and data analyses}

The search process retrieved a total of 241 records. After duplicates were removed, 196 records were examined by two pairs of reviewers independently. By screening them against the inclusion and exclusion criteria, 166 records were rejected (quantitative studies using standardized questionnaires; clinical screenings oriented on PD clinical phenomenology; intervention studies; systematic reviews, meta-analysis; theoretical discussions; studies focused on other neurological states or diseases). The remaining 30 studies were examined as full-text articles, and 10 were excluded as they reflected the perspectives of patient caregivers or spouses. 20 studies were included in the evaluation of methodological quality using CASP Qualitative Checklist. Of these, 4 were rejected as they didn't meet the criteria determined by the reviewers of an appraisal score of at least 8 "yes" answers on 10 CASP checklist questions. Any differences in the opinion of two pairs of reviewers in each phase of the retrieval process were resolved by co-operative discussion with other reviewers. The flow of information through different phases of selection and sorting the studies is reported in Diagram 1. The study selection process resulted in the detection of 16 qualitative studies relevant to the aim of our review. Their methodological characteristics are presented in Table 1.

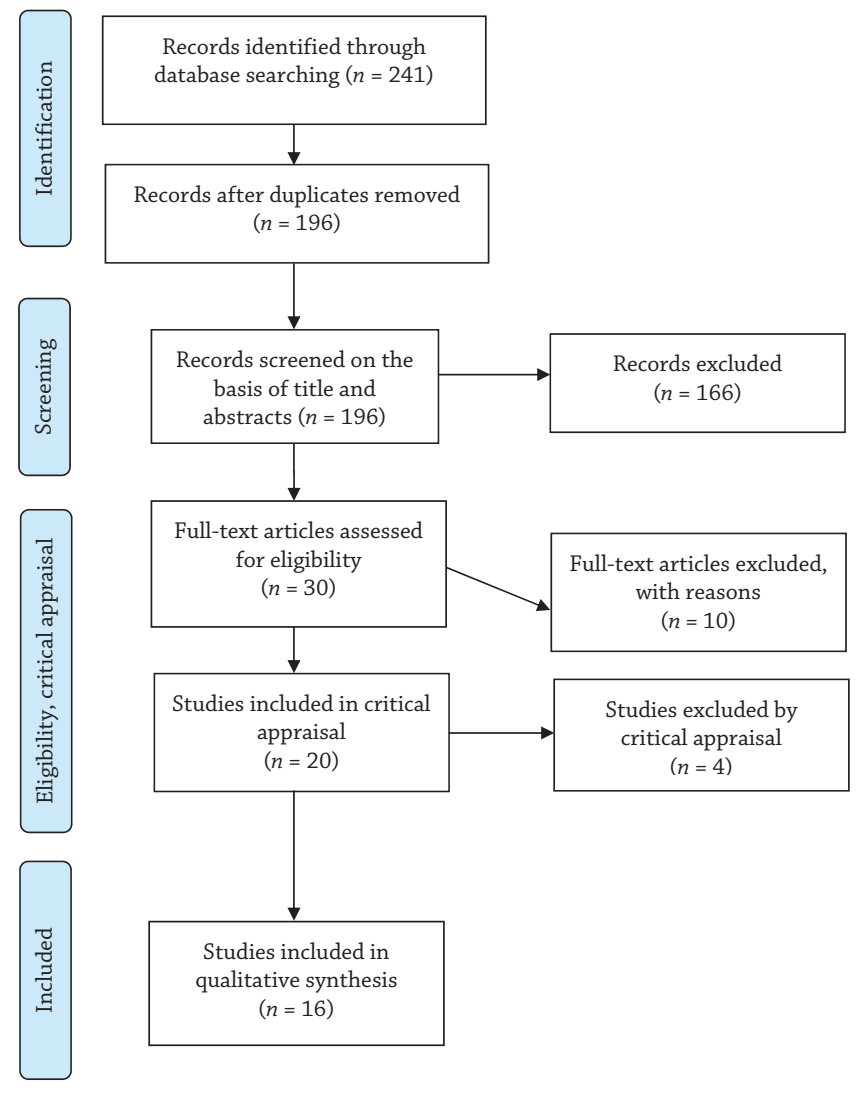

Diagram 1. Phases and results of the process of selection and sorting the studies (The PRISMA Statement flow diagram)

\section{Data extraction and thematic synthesis}

The findings of selected studies were extracted and synthesised by two independent reviewers using the thematic synthesis method. Findings in all studies were identified in the form of original subthemes and their descriptions were made concrete by patients' quotations. The synthesis proceeded in three stages: (1) free 'line-by-line' coding of the findings; in this stage 66 initial codes emerged; (2) organization of these 'free codes' into related areas based on similarities and differences to construct 'descriptive' themes capturing the meaning of groups of initial codes; 36 descriptive themes were generated; and (3) development of 'analytical' themes representing a stage of generating new interpretive constructs, additional concepts, explanations or understanding; and a final 6 analytical themes were synthesised (Thomas and Harden, 2008). Within the third stage of synthesis, each of the reviewers first assessed the descriptive themes independently and then then results were discussed in a group. A final version of synthesis was created based on reviewers' consensus.

\section{Results}

Six main synthesised themes expressing the real-life experience of PD patients were generated from the primary studies included in our literature review: Changing body; Range of emotional responses; Changing identity, self-worth and purpose; Social life limitations and challenges; Life control; and Future perspectives (Table 2). 
Table 1. Methodological characteristics of qualitative studies included

\begin{tabular}{|c|c|c|c|c|c|c|c|}
\hline Study & Aim & Sample & Methodology & $\begin{array}{l}\text { Data } \\
\text { collection }\end{array}$ & Data analysis & Credibility & CASP \\
\hline $\begin{array}{l}\text { Bramley and } \\
\text { Eatough } \\
\text { (2005), UK }\end{array}$ & $\begin{array}{l}\text { Individual's } \\
\text { personal } \\
\text { experience of } \\
\text { living with PD }\end{array}$ & 1 woman & IPA & $\begin{array}{l}\text { Semi-structured } \\
\text { interview }\end{array}$ & $\begin{array}{l}\text { IPA and } \\
\text { idiographic } \\
\text { approaches }\end{array}$ & $\begin{array}{l}\text { Peer debriefing, } \\
\text { Participant's } \\
\text { check }\end{array}$ & 10 \\
\hline $\begin{array}{l}\text { Eatough } \\
\text { and Shaw } \\
\text { (2017), UK }\end{array}$ & $\begin{array}{c}\text { Experience of } \\
\text { undergoing DBS }\end{array}$ & 1 woman & $\begin{array}{c}\text { Hermeneutic } \\
\text { phenomenological } \\
\text { exploration }\end{array}$ & $\begin{array}{l}\text { Semi-structured } \\
\text { interview }\end{array}$ & Thematic analysis & $\begin{array}{l}\text { Researcher's } \\
\text { reflexivity }\end{array}$ & 8 \\
\hline $\begin{array}{l}\text { Eccles et al. } \\
\text { (2011), UK }\end{array}$ & $\begin{array}{l}\text { Perception of the } \\
\text { cause and control } \\
\text { of the disease }\end{array}$ & $\begin{array}{c}11 \\
\text { participants }\end{array}$ & IPA & Interview & $\begin{array}{l}\text { IPA and } \\
\text { idiographic } \\
\text { approaches }\end{array}$ & $\begin{array}{l}\text { Triangulation of } \\
\text { researches }\end{array}$ & 10 \\
\hline $\begin{array}{l}\text { Gibson } \\
\text { (2016), UK }\end{array}$ & $\begin{array}{c}\text { Experience of } \\
\text { taking medications }\end{array}$ & 14 men & $\begin{array}{l}\text { Phenomenological } \\
\text { methodology }\end{array}$ & $\begin{array}{l}\text { Biographic narrative } \\
\text { interview and semi- } \\
\text { structured interview }\end{array}$ & Narrative analysis & $\begin{array}{l}\text { Researcher's } \\
\text { reflexivity }\end{array}$ & 9 \\
\hline $\begin{array}{l}\text { Gibson and } \\
\text { Kierans } \\
\text { (2017), UK }\end{array}$ & $\begin{array}{l}\text { Experience of } \\
\text { masculine, ageing } \\
\text { embodiment }\end{array}$ & 15 men & $\begin{array}{l}\text { Phenomenological } \\
\text { approach using } \\
\text { narrative methods }\end{array}$ & $\begin{array}{l}\text { Initial narrative } \\
\text { interview and semi- } \\
\text { structured interview }\end{array}$ & Narrative analysis & $\begin{array}{l}\text { Researcher's } \\
\text { reflexivity }\end{array}$ & 9 \\
\hline $\begin{array}{l}\text { Haahr et } \\
\text { al. (2010), } \\
\text { Denmark }\end{array}$ & $\begin{array}{l}\text { Living following } \\
\text { DBS }\end{array}$ & 9 patients & $\begin{array}{c}\text { Hermeneutic } \\
\text { phenomenological } \\
\text { methodology of Van } \\
\text { Manen }\end{array}$ & $\begin{array}{l}\text { Qualitative in-depth } \\
\text { interview }\end{array}$ & $\begin{array}{c}\text { Hermeneutic } \\
\text { phenomenological } \\
\text { methodology of } \\
\text { Van Manen }\end{array}$ & $\begin{array}{l}\text { Researcher's } \\
\text { reflexivity }\end{array}$ & 10 \\
\hline $\begin{array}{l}\text { Haahr et } \\
\text { al. (2011), } \\
\text { Denmark }\end{array}$ & $\begin{array}{l}\text { Experience of life } \\
\text { before and after } \\
\text { DBS treatment }\end{array}$ & $\begin{array}{l}11 \\
\text { participants }\end{array}$ & $\begin{array}{c}\text { Hermeneutic } \\
\text { phenomenological } \\
\text { methodology of Van } \\
\text { Manen }\end{array}$ & In-depth interview & $\begin{array}{c}\text { Hermeneutic } \\
\text { phenomenological } \\
\text { methodology of } \\
\text { Van Manen }\end{array}$ & $\begin{array}{l}\text { Researcher's } \\
\text { reflexivity }\end{array}$ & 10 \\
\hline $\begin{array}{l}\text { McClurg et } \\
\text { al. (2016), } \\
\text { UK }\end{array}$ & $\begin{array}{l}\text { Experience of } \\
\text { constipation } \\
\text { management }\end{array}$ & $\begin{array}{l}7 \text { participants } \\
\text { from } \\
\text { intervention } \\
\text { group and } 7 \\
\text { patients from } \\
\text { control group }\end{array}$ & $\begin{array}{c}\text { Phenomenological } \\
\text { methodology }\end{array}$ & $\begin{array}{l}\text { Semi-structured } \\
\text { interview }\end{array}$ & $\begin{array}{l}\text { Constant- } \\
\text { comparative } \\
\text { technique, } \\
\text { descriptive } \\
\text { analysis }\end{array}$ & $\begin{array}{l}\text { Cross control of } \\
\text { researchers }\end{array}$ & 9 \\
\hline $\begin{array}{l}\text { Nazzal } \\
\text { and Khalil, } \\
\text { (2017) } \\
\text { Jordan }\end{array}$ & $\begin{array}{l}\text { Experience of how } \\
\text { disease affects } \\
\text { daily life }\end{array}$ & 8 participants & $\begin{array}{l}\text { Phenomenological } \\
\text { approach }\end{array}$ & $\begin{array}{l}\text { Semi-structured } \\
\text { interview }\end{array}$ & $\begin{array}{l}\text { Content thematic } \\
\text { analysis approach }\end{array}$ & $\begin{array}{l}\text { Triangulation of } \\
\text { researches }\end{array}$ & 10 \\
\hline $\begin{array}{l}\text { Olsson and } \\
\text { Nilsson } \\
\text { (2015), } \\
\text { Sweden }\end{array}$ & $\begin{array}{c}\text { Meanings of } \\
\text { feeling well as } \\
\text { experienced by } \\
\text { women with PD }\end{array}$ & 9 women & $\begin{array}{l}\text { Phenomenological } \\
\text { approach }\end{array}$ & Narrative interview & RLR & $\begin{array}{l}\text { Triangulation of } \\
\text { researches }\end{array}$ & 10 \\
\hline $\begin{array}{l}\text { Redmond } \\
\text { and Suddick } \\
\text { (2012), UK }\end{array}$ & $\begin{array}{l}\text { Experience of } \\
\text { freezing }\end{array}$ & 6 participants & $\begin{array}{c}\text { Interpretive } \\
\text { phenomenological } \\
\text { approach }\end{array}$ & $\begin{array}{c}\text { Face-to-face } \\
\text { interview and } \\
\text { telephone interview }\end{array}$ & $\begin{array}{c}\text { Inductive thematic } \\
\text { analysis }\end{array}$ & Peer debriefing & 10 \\
\hline $\begin{array}{l}\text { Sheehy et al. } \\
\text { (2016), USA }\end{array}$ & $\begin{array}{l}\text { Experience of } \\
\text { social interactions, } \\
\text { social support, } \\
\text { social comparison, } \\
\text { and physical } \\
\text { challenges in a } \\
\text { group exercise } \\
\text { programme }\end{array}$ & $\begin{array}{c}20 \\
\text { participants } \\
\text { in group } \\
\text { exercise }\end{array}$ & IPA & $\begin{array}{l}\text { Semi-structured } \\
\text { interview }\end{array}$ & $\begin{array}{l}\text { Coding, } \\
\text { idiographic process } \\
\text { and IPA }\end{array}$ & $\begin{array}{l}\text { Triangulation of } \\
\text { researches, Peer } \\
\text { debriefing }\end{array}$ & 10 \\
\hline $\begin{array}{l}\text { Simpson et } \\
\text { al. (2015), } \\
\text { UK }\end{array}$ & $\begin{array}{l}\text { Experience of } \\
\text { apathy }\end{array}$ & 7 men & $\begin{array}{l}\text { Phenomenological } \\
\text { approaches }\end{array}$ & $\begin{array}{l}\text { Semi-structured } \\
\text { interview }\end{array}$ & IPA & $\begin{array}{l}\text { Peer checking } \\
\text { process by first } \\
\text { author }\end{array}$ & 10 \\
\hline $\begin{array}{l}\text { Sunvisson } \\
\text { and Ekman } \\
\text { (2001), } \\
\text { Sweden }\end{array}$ & $\begin{array}{l}\text { Environmental } \\
\text { influences on lived } \\
\text { illness experience }\end{array}$ & $\begin{array}{c}11 \\
\text { participants }\end{array}$ & $\begin{array}{l}\text { Phenomenological } \\
\text { approach }\end{array}$ & Interview & $\begin{array}{l}\text { Phenomenological } \\
\text { method }\end{array}$ & $\begin{array}{l}\text { Researcher's } \\
\text { reflexivity }\end{array}$ & 10 \\
\hline $\begin{array}{l}\text { Sunvisson } \\
\text { (2006), } \\
\text { Sweden }\end{array}$ & $\begin{array}{c}\text { Experience of late- } \\
\text { stage PD }\end{array}$ & 1 woman & $\begin{array}{l}\text { Phenomenological } \\
\text { method }\end{array}$ & $\begin{array}{l}\text { Interview during the } \\
\text { five-year period }\end{array}$ & $\begin{array}{l}\text { Phenomenological } \\
\text { method developed } \\
\text { by Karlsson }\end{array}$ & $\begin{array}{l}\text { Researcher's } \\
\text { reflexivity }\end{array}$ & 9 \\
\hline
\end{tabular}


Table 1 (Continued)

\begin{tabular}{|c|c|c|c|c|c|c|c|}
\hline Study & Aim & Sample & Methodology & $\begin{array}{c}\text { Data } \\
\text { collection }\end{array}$ & Data analysis & Credibility & CASP \\
\hline $\begin{array}{l}\text { Turner et } \\
\text { al. (2017), } \\
\text { Australia }\end{array}$ & $\begin{array}{l}\text { Anxiety and worry } \\
\text { as it relates to } \\
\text { driving and driving } \\
\text { cessation for } \\
\text { patients and their } \\
\text { families }\end{array}$ & $\begin{array}{l}\text { Two groups } \\
\text { presented } \\
\text { separately,20 } \\
\text { patients,12 } \\
\text { family } \\
\text { members }\end{array}$ & $\begin{array}{c}\text { Qualitative } \\
\text { methodology } \\
\text { and descriptive } \\
\text { phenomenological } \\
\text { approach }\end{array}$ & $\begin{array}{c}\text { Semi-structured } \\
\text { interview }\end{array}$ & $\begin{array}{c}\text { Inductive thematic } \\
\text { analysis }\end{array}$ & $\begin{array}{l}\text { A peer checking } \\
\text { process }\end{array}$ & 10 \\
\hline
\end{tabular}

Legend: PD, Parkinson's disease; IPA, Interpretative phenomenological analysis; RLR, Reflective lifeworld research approach; DBS, Deep brain stimulation; CASP, Critical Appraisal Skills Programme.

Table 2. Overview of synthesised themes expressing the PD patients' real-life experience

\begin{tabular}{|c|c|c|c|c|c|c|}
\hline $\begin{array}{l}\text { Analytical } \\
\text { themes }\end{array}$ & Changing body & $\begin{array}{l}\text { Range of } \\
\text { emotional } \\
\text { responses }\end{array}$ & $\begin{array}{c}\text { Changing identity, } \\
\text { self-worth and } \\
\text { purpose }\end{array}$ & $\begin{array}{c}\text { Social life } \\
\text { limitations and } \\
\text { challenges }\end{array}$ & Life control & Future perspectives \\
\hline \multirow{12}{*}{$\begin{array}{l}\text { Descriptive } \\
\text { themes }\end{array}$} & $\begin{array}{l}\text { DBS and embodied } \\
\text { meaning }\end{array}$ & Anxiety & Changed status & $\begin{array}{c}\text { Insecurity in social } \\
\text { events }\end{array}$ & $\begin{array}{l}\text { Being enslaved/ } \\
\text { Loss of control }\end{array}$ & Expectations \\
\hline & An alien body & $\begin{array}{l}\text { Psychological } \\
\text { distress/Burden }\end{array}$ & My mission in life & Stigma & Adaptation & Decision \\
\hline & $\begin{array}{c}\text { Threatened } \\
\text { masculine visceral } \\
\text { embodiment }\end{array}$ & Apathy & $\begin{array}{l}\text { Confidence in } \\
\text { oneself }\end{array}$ & $\begin{array}{l}\text { Positive influence } \\
\text { of social gatherings }\end{array}$ & $\begin{array}{l}\text { Supportive/Safe } \\
\text { space }\end{array}$ & Trajectory \\
\hline & Freezing & $\begin{array}{l}\text { Fluctuation of } \\
\text { emotions }\end{array}$ & Athletic identity & Being connected & $\begin{array}{c}\text { Balancing } \\
\text { acceptance and } \\
\text { denial }\end{array}$ & $\begin{array}{c}\text { Liberation /Freedom / } \\
\text { Miracle }\end{array}$ \\
\hline & & Uncertainty & & & Breaking taboos & Reflection of future self \\
\hline & & Emotional drain & & & $\begin{array}{l}\text { Struggling with } \\
\text { unpredictability }\end{array}$ & \\
\hline & & $\begin{array}{l}\text { Finding peace } \\
\text { and harmony }\end{array}$ & & & $\begin{array}{c}\text { Efforts to } \\
\text { control changing } \\
\text { conditions }\end{array}$ & \\
\hline & & & & & Medication & \\
\hline & & & & & Exercising & \\
\hline & & & & & DBS & \\
\hline & & & & & Education & \\
\hline & & & & & $\begin{array}{c}\text { Movement } \\
\text { fragmentation }\end{array}$ & \\
\hline
\end{tabular}

\section{Changing body}

The changing body represents the significant and intensive lived experience of patients with PD, with bodily changes striking patients' everyday lives. The body is perceived as an alien body, not working as usual, acting funnily with unpredictable body reactions as an impact of freezing or disabling ON and OFF phenomena (Eatough and Shaw, 2017; Gibson and Kierans, 2017; Haahr et al., 2011; Olsson and Nilsson, 2015; Redmond and Suddick, 2012). In studies by Haahr et al. (2011) and Redmond and Suddick (2012), the perception of an alien body was described as a 'missing link' between mind and body. Such altered body sensations affected both the self-esteem and the perception of identity. Sunvisson (2006) stressed the experience of one female patient with unpredictable body reactions sabotaging the achievement of her planned actions. Redmond and Suddick (2012) introduced patients' experience of freezing, which is described as heightened physical and bodily awareness while simultaneously feeling separate and alienated from their body. After freezing had passed, the body was once more familiar and present. Gibson and Kierans (2017) findings in men suggest, that PD threatened their body in the sense of masculine visceral embodiment, specifically in terms of basic movements and intimate bodily functions. Apart from shaking, stiffness in the muscles, losing stamina or becoming fatigued, it was drooling, incontinence and sexual dysfunction that posed the most explicit challenge to masculine self-image in these men. The changing body senses and perceptions experienced in one female patient in relation to the undergoing of deep brain stimulation (DBS) were pointed out by Eatough and Shaw (2017) as the embodied meaning of DBS. Prior to DBS she imagined this procedure as a brutal assault on her body ending with her death, and post-operatively she utilized avoidance and rational deliberation to aid in the adjustment to her changed body.

\section{Range of emotional responses}

Patients with PD describe a wide spectrum of emotional reactions, states and feelings experienced in different stages of the 
disease trajectory (Eatough and Shaw, 2017; Eccles et al., 2011; Kalia and Lang, 2015; McClurg et al., 2016; Nazzal and Khalil, 2017; Olsson and Nilsson, 2015; Sheehy et al., 2016; Simpson et al., 2015; Turner et al., 2017). PD was an emotional drain during the diagnosis story, when patients experienced helplessness, hopelessness and depression, many of them felt pity and started to question the disease: Where did it come from? Why them? (Nazzal and Khalil, 2017). As for the cause of the disease, patients experienced the feelings of certainty and uncertainty simultaneously (Eccles et al., 2011). The analysis of one female patient's feelings after DBS therapy in the study by Eatough and Shaw (2017) pointed to the complexity of experienced emotional states and revealed fluctuating emotions, e.g. 'terrified', 'disappointed', 'excited', 'overjoyed'. Sheehy et al. (2016) introduced patients experiencing anxiety, depression and stress in relation to PD. For many of them such feelings were connected with the option of joining the programme of group exercise. In the study of McClurg et al. (2016) negative experiences of constipation resulting in psychological distress and burden were shown, expressed as feelings of embarrassment and being unhappy. Turner et al. (2017) revealed how the experience of anxiety while driving as well as worries related to driving cessation, affected wellbeing of PD patients. Simpson et al. (2015) stressed the experience of apathy and how it reduced motivation or emotional engagement and had an impact on social activities. In contrast, some participants in this study talked about the benefits of apathy, e.g. more relaxing. Olsson and Nilsson (2015) were focussed on meanings of feeling well as experienced by women with PD. They depicted the experience of finding peace and harmony. Women tried to move away from their bodies, forget the illness and feel free by directing themselves outwards into the surroundings, engaging in self-awareness, meditating, relaxing, viewing the colours when painting, taking a bath, a walk or exercising, or just doing things for their own sake.

\section{Changing identity, self-worth and purpose}

The significant impact of PD on a patient's identity and selfworth is experienced in relation to understanding one's mission in life, performing traditional roles, purposeful activities and tasks including work. Patients frequently experience personal and social consequences of impairment resulting in changing status (Bramley and Eatough, 2005; Gibson and Kierans, 2017; Olsson and Nilsson, 2015; Sheehy et al., 2016; Simpson et al., 2015; Sunvisson, 2006). Some patients had to finish work because of PD, and this was experienced as the loss of a meaningful role and purposeful activity, which was incongruent with their self-identity. Taking on different roles was difficult and negatively impacted their sense of self-worth (Simpson et al., 2015). Men described how PD symptoms affected their body's ability to complete a range of stereotypically masculine forms of labour (employment, tasks including DIY, gardening, car maintenance, electrical rewiring or plumbing, sports and hobbies) and identities expressed through them. Tasks such as lifting, carrying or digging became more difficult. Tremors restricted dexterous, skilled work, while fatigue left them struggling to keep up with others (Gibson and Kierans, 2017). One female PD patient continuously sought new ways to remain faithful to her understanding of what she believed to be her mission in life: she tried to engage the staff in the wards and make them aware of how the caring of patients could be improved, or discussed with relatives how to live with PD (Sunvisson, 2006). Olsson and Nilsson (2015) described how women with PD felt well by being themselves and letting go of their facade. Bramley and Eatough (2005) asked one female patient to describe herself prior to diagnosis - she gave priority to her role of wife and mother, seeing herself as active and competent, and her confidence was derived from these. Her idealised 'former self' contrasted considerably with her 'current self' - at present she perceived the disease to have stolen "the opportunity to make the most of herself". This has had a negative impact on her sense of femininity. In the study of Sheehy et al. (2016), joining the exercise programme had a positive impact on maintaining a sense of athletic identity in PD patients who were accustomed to feeling physically competent.

\section{Social life limitations and challenges}

The negative impact of PD on social life dominated patients' experience, particularly in terms of social restrictions, isolation and stigma. On the other hand, many patients stressed that their participation in social events had a positive effect on their life with the disease (Haahr et al., 2011; Nazzal and Khalil, 2017; Olsson and Nilsson, 2015; Sunvisson, 2006; Sunvisson and Ekman, 2001). Feelings of insecurity in social events were found in some of the study participants (Sunvisson and Ekman, 2001), in which the feeling of anxiety to be with other people was an obstacle to social interaction, causing social life limitations. They were aware of their physical and psychological shortcomings and felt embarrassed in front of others. They spoke of putting on a 'brave face', and they assumed this for variety of reasons: the wish to hide shortcomings, to protect their social authority, to avoid being the subject of gossip, not wanting to be pitied, or not wanting friends to be embarrassed in their company. Similarly, participants in the study (Haahr et al., 2011) felt restricted due to dependency on others while going out. Limited social relations and social life were related to loss of holidays, having a selective social circle consisting of close family and old friendships, or making a shift to spending more time with other PD patients. Nazzal and Khalil (2017) identified patients' perception of stigma, as they experienced staring and sometimes laughing at their odd gait. Therefore, attempting to hide their disease by socially isolating themselves was common among all participants. Sunvisson (2006) described the meaning of social gatherings for one female patient, stressing that through social gatherings she became totally unconscious of her body and felt her appearance didn't show signs of illness. Also, Olsson and Nilsson (2015) showed that for women with PD the feeling of being connected with others is equal to feeling well. Family was an important source of feeling well and sharing joy, bringing happiness to their lives.

\section{Life control}

Experience with life control was presented in studies from two perspectives: disease controls the patient's life, and the patient's efforts to manage life with the disease. Within the first of these perspectives, patients with PD experience loss of control regarding their body movements and thoughts due to the unpredictability of PD's symptoms and the medication's side effects, resulting in a problematic managing of their daily routines, and a sense of losing control over social connections and social situations (Bramley and Eatough, 2005; Gibson, 2016; Sunvisson and Ekman, 2001; Turner et al., 2017). Sunvisson and Ekman (2001) identified that patients experienced a sense of being enslaved by the illness. This originated from unpredictable expressions of the illness and was manifested in loss of control regarding their body movements and thoughts. For participants in this study, many desired activities were simply unattainable; they felt little control over family, social situa- 
tions, and their own future. In relation to loss of control, Turner et al. (2017) stressed patients' worries about losing freedom and independence and becoming a burden on others after stopping driving. Gibson (2016) concentrated on patients' experience of symptom control by medication. They stressed that forgetting medication-time meant instant payback in terms of immobility. As a result of vivid bodily sensations 'kicking in' after medication, the body was experienced to be out of their control. A loss of control over taken-for-granted basic functions after medication was also described by another study (Bramley and Eatough, 2005), where a patient stressed that medication allowed her to become 'free' from disease constraints and get on with daily life. However, restored movement was often coupled with uncomfortable side effects of extreme involuntary movement.

In the second perspective of the theme of life control, patients expressed the desire and efforts to manage their life with the disease through participation in exercise and support groups, education, movement fragmentation (movements are divided into smaller parts), direct mental concentration on movements, and the help from their spouses. Patients after DBS experience participating in new activities and integrating new aspects of life, and having the opportunity to live more spontaneously (Eccles et al., 2011; Gibson, 2016; Gibson and Kierans, 2017; Haahr et al., 2010; McClurg et al., 2016; Nazzal and Khalil, 2017; Olsson and Nilsson, 2015; Sheehy et al., 2016; Sunvisson, 2006; Sunvisson and Ekman, 2001). Three used strategies were identified by Haahr et al. (2010) as a way of managing life with the disease: being positive to keep motivation for sustaining as normal life as possible; being in control to minimize the need for help for as long as possible; and living according to a routine. In the study of Sheehy et al. (2016), many patients entering a group exercise programme praised the supportive and safe space allowing them to share their lived experience with people with the same diagnosis. The support from trainers was seen as extraordinary in terms of understanding their specific needs and challenges and being empathetic. Breaking taboos by sharing the humour about PD alleviated anxiety about the disease, reduced stress and cemented shared connections in the group. Balancing acceptance and denial during the adaptation process was experienced by participants in another study (Eccles et al., 2011) trying to come to terms with the illness and yet get on with their lives. Some talked about activities that had to be adapted, e.g. soup could be eaten from a cup instead of a plate, or peas could be eaten with a spoon. These adaptations meant that social and personal consequences could be minimised. Nazzal and Khalil (2017) reported the adaptations of participants as follows: embracing early intervention, spirituality and family support. Sunvisson (2006) introduced some efforts to control the changing conditions by one female patient, trying to understand how various environmental, emotional, physical, and life conditions interrelate with the expression of her illness and her capability to deal with it. She believed her own medical schedule and reducing animal protein intake could help achieve a smoother mobility pattern. She discovered visualization to reduce some symptoms of PD, e.g. she can carry out an intention by transporting mobility problems to another part of her body. The importance of planning daily life for women with PD was described by Olsson and Nilsson (2015). The women described how feeling well meant being in control and having the opportunity to choose how their days would be spent. Participants in another study (McClurg et al., 2016) tried to deal with the serious problem of constipation through implement- ing dietary changes before deciding to take laxatives. Eccles et al. (2011) presented the attitude to medication in PD patients, who, despite finding various creative ways of regaining control over their bodies, still considered medication to be the main method of control. Patients in the study (Sunvisson and Ekman, 2001) stressed the use of movement fragmentation to control the body. Movements had to be cognitively divided into smaller parts, producing fumbled, slow and imprecise body performance with reduced movement fluidity perceived in the sense of losing control. Such direct mental concentration automatically and quickly consumed energy, necessitating a careful prioritizing of routine daily activities. Sunvisson (2006) also described patient experience with fragmented embodied skilfulness requiring concentration and attention. Similarly, men in another study (Gibson and Kierans, 2017) stressed the necessity of increased concentration on activities. Specifically, one patient described how he had to verbally tell his body how and when to move. These aspects of navigating and negotiating became the source of a new and embodied interaction with the self. Participants in the study by Haahr et al. (2010) had undergone DBS treatment. They concluded that their life was changed following DBS and new aspects of life were integrated. They stressed more control over the body and more choice in what to do and when. This allowed them to live more spontaneously; not being left to plan things 'in between' medication times as had been the case before DBS.

\section{Future perspectives}

As PD is a life-limiting illness, patients use it to engage in thinking about their future and reflect on their possible future selves in both the negative but also positive way. In the trajectory of PD, medication and DBS treatment represent significant milestones pointing at the speed at which illness progresses. This puts demands on the patients in terms of the decision-making process (Eatough and Shaw, 2017; Gibson, 2016; Haahr et al., 2011; Sheehy et al., 2016; Sunvisson, 2006). Eatough and Shaw (2017) described one female patient's experience with making decisions in relation to her future perspectives. She was faced with the idea of her own death and the awareness that her life is finite. DBS was suggested as an option for her. She felt fearful and alarmed as "her Parkinson's" had assumed a more threatening status. Expectations in relation to participants' life changes after DBS were described (Haahr et al., 2011). Patients expressed hope for a more stable life, and not being so dependent on medication. The wish to be able to walk, to be more active and achieve other things in life was very profound. Straight after DBS, participants described the experience of being liberated from illness and an overall feeling of 'freedom to do and decide'. Many used the term 'miracle' to describe their new situation. Participants in group exercises struggled with anxiety about seeing others at more advanced stages of PD, which led them to reflect on their possible future selves (Sheehy et al., 2016). In another study, men with PD knew their condition would get worse, even though it could take many years to do so. They focused on questions such as how much time they had left before death or before PD stopped them from living a meaningful life. Medication held a metaphorical significance as signposts along the PD journey, with levodopa being one of the first significant steps on the PD path (Gibson, 2016). Sunvisson (2006) described the reflection of a female patient perspective in late-stage PD. Her increasing fragility led her to experience her narrow world more intensely. She developed new concentration and density; thus her future visions became limited to the life here and now. 


\section{Discussion}

Lived experience is always essentially one's own direct experience (Burch, 1990). Qualitative research provides an in-depth description, understanding and explanation of patients' experience of the disease and its treatment (O'Cathain et al., 2014). In our study, we synthesized 16 qualitative studies presenting individual real-life experience of PD patients. Synthesised themes also point to the possibility of studying the life experience of $\mathrm{PD}$ patients through the concept of human dignity (Jacobson, 2012; Matiti and Baillie, 2011; Nordenfelt, 2009) as all themes are closely connected with this concept.

Clinical manifestation of PD is represented by a set of motor and non-motor symptoms (Kalia and Lang, 2015). Characteristic signs and symptoms result in everyday efforts of coexistence with the new situation (Valcarenghi et al., 2018). This is reflected in patients' perception of the changing body (Eatough and Shaw, 2017; Gibson and Kierans, 2017; Haahr et al., 2011; Olsson and Nilsson, 2015; Redmond and Suddick, 2012). The perception of physical changes is also affected by available therapies for PD (Valcarenghi et al., 2018). Women interviewed in a study (Caap-Ahlgren and Lannerheim, 2002) stressed the dominant sensation of being less physically competent or totally incompetent, despite the fact that fluctuation in physical competence was confirmed; mainly in relation to on and off periods. In many of them, motor disturbances and functional impairment hampered the performance of traditional female competence.

PD patients experience a wide range of emotional states in response to the life events strongly influenced by PD. They experience anxiety, fear, uncertainty, apathy, and psychological distress (Eatough and Shaw, 2017; Eccles et al., 2011; McClurg et al., 2016; Nazzal and Khalil, 2017; Sheehy et al., 2016; Simpson et al., 2015; Turner et al., 2017). Rod et al. (2013) found association between various acute life events (e.g. close relative or spouse died, separated or divorced, or retired) and chronic life events (e.g. financial crisis, serious problems in relationships) experienced in new-onset PD patients and the risk of depression. They even confirmed the development of a major depression in almost $10 \%$ of their sample.

Changing identity, self-worth and purpose falls into the life experience of PD patients, forming the basis of their decisions and behaviours (Bramley and Eatough, 2005; Gibson and Kierans, 2017; Olsson and Nilsson, 2015; Sheehy et al., 2016; Simpson et al., 2015; Sunvisson, 2006). In a chronic disease such as PD, perceptions and attitudes of individuals toward themselves are considered to have an important influence on the quality of self-care behaviours (Soleimani et al., 2016). In this study, patients with negative self-concepts became more passive in their self-care over time. Patients with positive attitudes did not view the disease changes as a shortcoming. These patients looked for other resources such as family members, friends and religious beliefs to meet their needs. The qualitative study of Charlton and Barrow (2002) identified the loss of identity in PD patients. Participants perceived PD as a threat to their identity, either by being labelled as a person with disabilities or a sufferer of a disease, or by acknowledging that they were no longer able to act in the ways which were characteristic of them. The self-concept determined individual's social fate and their quality of life in general. Caap-Ahlgren and Lannerheim (2002) pointed to the presence of suffering from low self-confidence in women. They expressed the need for encouragement of personal value and feelings of confidence and trust. At the same time they stressed their wish for a stable body image, to keep traditional competence and to be accepted by others. Based on systematic review (Soundy et al., 2014), authors have stated that health care professionals working with PD patients should have a better understanding of patients' social identities. It is important to recognise that PD influences an individual's social identity or sense of self. Social identity was established as a key factor influencing an individual's well-being.

PD patients experience limitations and challenges in social life (Haahr et al., 2011; Nazzal and Khalil, 2017; Olsson and Nilsson, 2015; Sunvisson, 2006; Sunvisson and Ekman, 2001). Soleimani et al. (2016) ascertain decreasing social connectedness of patients due to their disease. Social connectedness of patients had been limited by the loss of their employment and the need for early retirement. Social connectedness disrupted feelings of shame and embarrassment and concealing oneself from others. Valcarenghi et al. (2018) pointed to the prejudice experienced by people with PD, which may occur due to characteristics of the disease, such as tremors, stiffness and difficulty walking. Soleimani et al. (2014) indicated that the debilitating effects of PD with psychological distress caused patients to avoid participation and involvement in the community. Social events might cause severe psychological distress such as anxiety, resulting in social withdrawal. Similarly, Caap-Ahlgren and Lannerheim (2002) mentioned feelings of discomfort with social contacts in PD patients who were afraid of being negatively evaluated in public, as symptoms like the so-called 'masked face' and 'muffled voice', caused them to feel ashamed at having this disease. The need for a feeling of belonging is important to PD patients and their partners, and such feelings can be achieved through social engagement and companionship by means of support groups (Olsson and Nilsson, 2015; Smith and Shaw, 2017). Charlton and Barrow (2002) identified the social interaction of patients as one of the coping methods related to the enjoyment of experiences involving other people where the experience had usually arisen as a direct result of the illness. The findings of these studies indicate that support can help patients to proactively come to terms with what PD means for them in order to accept it and to make necessary adjustments to their lifestyle. Conflicting findings of previously mentioned studies exploring the meaning of social interaction for PD patients point to a different experience that is individual and unique for each patient - on one hand the effect of social interaction may be beneficial but on the other hand patients can be afraid of social contacts.

Experience with life control in relation to PD was presented in analysed studies (Bramley and Eatough, 2005; Gibson, 2016; Sunvisson and Ekman, 2001; Turner et al., 2017) from two perspectives: disease controls the life of the patient, and the patient's effort to manage life with the disease. The experience of feeling a loss of control in PD patients includes the loss of the ability to do things due to impaired physical function; the unpredictability of everyday life and the associated inability to plan ahead (loss of freedom); weakened social ties, friendships and relationships; loss of choice, hobbies and work; loss of time as medication regimen is predominant; loss of elements of relationships with spouses, for example, intimacy, joint activities; loss of independence and time for oneself; and loss of companionship (Mathers et al., 2016; Suddick and Chambers, 2010).

Mainly late stage PD is characterised by a perceived loss of control over the disease and its impacts due to increased lack of predictability (Mathers et al., 2016). The experience of taking medications is challenging for patients as many use multiple medications. Side effects from medication and difficulty 
in relation to dosages required were reported in some studies. The use of continuous-use medication can increase the suffering and discomfort (Valcarenghi et al., 2018). Coping with the disease in everyday life is challenging for PD patients (Eccles et al., 2011; Gibson, 2016; Haahr et al., 2010, 2017). Adapting to a life with PD requires pro-active adjustments to assimilate PD into everyday life (Smith and Shaw, 2017). Charlton and Barrow (2002) describe the "fighting spirit" of the patients in relation to the efforts to maintain as normal life as possible despite the disease.

The last of the themes generated from primary studies was future perspectives (Eatough and Shaw, 2017; Gibson, 2016; Haahr et al., 2011; Sheehy et al., 2016; Sunvisson, 2006) in the sense of the reduction of hope for the future. Significant factors (medication, DBS, progression of PD) were identified in the trajectory of patients' lives affecting their perception of the future. Perception of the loss of future perspectives was also identified by Charlton and Barrow (2002), specifically, patients expressed the presence of an increased sense of mortality. DBS is considered one of the factors promoting hope to counteract the progressive impact and decline associated with PD (Haahr et al., 2011; Mathers et al., 2016). On the other hand, patients experience behaviour changes that are more difficult than they had prepared for prior to the DBS (Liddle et al., 2018). Sheehy et al. (2016) declared that patients participating in an exercise programme witnessed their teammates with more advanced symptoms and they became role models and examples of coping and succeeding. This shift helped them to see their life in a new light and gave them hope for the future. Smith and Shaw (2017) oriented their study on the analysis of well-being in patients with PD and their relatives, identifying the theme of "Carpe diem!" This described the changes in participants' perception of time in the sense of enjoying the pleasure of the moment with no concerns for the future.

Valcarenghi et al. (2018) showed that knowing and understanding the factors interfering in the day-to-day experience of $\mathrm{PD}$ patients improves and guides the care provided by professionals. For patients, it is not enough to focus only on the physical aspects of the disease; they must also focus on maintaining social relations, independence and autonomy for longer. Understanding this experience is crucial for health care professionals, so they can also be attentive to patients' feelings and needs. Nurses should have a key role in providing education, advice, ongoing support, and encouraging autonomy and self-efficacy of PD patients to help them cope with the worsening journey (Suddick and Chambers, 2010). Knowledge on how people living with PD cope with the challenges of the disease is important for planning individualized care and rehabilitation (Haahr et al., 2017).

\section{Study limitations}

Our research was limited by only searching databases that were accessible from the authors' institution. The review was restricted to articles published in English only, thus there is also a possibility that relevant studies published in other languages were missed. Critical appraisal of qualitative studies and the thematic synthesis of qualitative findings were challenging tasks for the authors because of different levels of expertise in the field. For this reason, critical reflectivity was used to decrease possible bias. Even though all review processes were doubled, the authors realize the findings could be influenced by their previous research experience and their nursing and philosophical background.

\section{Conclusions}

The findings of qualitative studies concerning patients' experience may be important for health care professionals for their better understanding. These data may also be useful to guide further qualitative research of the issue of life experience of PD patients. Our review may be helpful in presenting a broad perspective on how PD patients experience their life with the disease by identifying six core themes: Changing body; Range of emotional responses; Changing identity, self-worth and purpose; Social life limitations and challenges; Life control; and Future perspectives, which facilitate our understanding of the real-life experience of PD patients. This review can be considered the first, preliminary step; the basis for conducting a systematic review of the life experience of patients with severe neurodegenerative conditions.

\section{Conflict of interests}

The authors have no conflict of interests to declare.

\section{Acknowledgements}

This research is supported by VEGA grant 1/0090/17: 'Dignity of patients with neurological disease in the context of healthcare: an interpretative phenomenological approach'.

\title{
Reálne životné skúsenosti pacientov s Parkinsonovou chorobou
}

\begin{abstract}
Súhrn
Parkinsonova choroba (PCH) má vel'ký dopad na pacientovu životnú skúsenost́. Doteraz chýbali literárne prehl'ady, vrátane systematických, orientovaných na reálnu životnú skúsenost' pacientov s PCH. Ciel'om bolo identifikovat', analyzovat', sumarizovat' a syntetizovat' zistenia z kvalitatívnych štúdií zameraných na životné skúsenosti pacientov s PCH. Realizovali sme kvalitatívnu prehl'adovú štúdiu. Pri vyhl'adávaní relevantných dokumentov boli použité elektronické databázy na rozhraní EBSCOhost v januári 2018: Academic Search Complete; Health Source: Nursing/Academic Edition and MEDLINE. Na posúdenie metodologickej kvality vyhl'adaných štúdií boli použité kritériá CASP (Qualitative Research Checklist). Na syntézu výsledkov vyhl'adaných kvalitatívnych štúdií bola zvolená tematická syntéza. Z 241 vyhl'adaných dokumentov bolo relevantných 16 kvalitatívnych štúdií. Tematickou syntézou bolo generovaných 6 hlavných tém: Zmenené telo; Rozsah emocionálnej reakcie; Zmena identity, sebaúcty a zmyslu; Limitácie a výzvy v sociálnom živote; Kontrola života a Perspektíva budúcnosti. Prehl'ad prináša širší pohl'ad na to, ako pacienti s PCH prežívajú svoj život s týmto ochorením. Zistenia môžu byt' užitočné pre zdravotníckych pracovníkov, aby lepšie porozumeli potrebe realizovat' na pacienta orientovanú starostlivost́. Naše zistenia môžu byt' usmernením pre d'alší kvalitatívny výskum problematiky životných skúseností pacientov s PCH, ako aj pre systematické skúmanie tejto problematiky.
\end{abstract}

Kl'účové slová: kvalitatívne štúdie; naratívny prehl'ad; pacient s Parkinsonovou chorobou; tematická syntéza; životná skúsenost' 


\section{References}

1. Bramley N, Eatough V (2005). The experience of living with Parkinson's disease: an interpretative phenomenological analysis case study. Psychol Health 20(2): 223-235. DOI: 10.1080/08870440412331296053.

2. Burch R (1990). Phenomenology, lived experience: Taking a measure of the topic. Phenomenology + Pedagogy 8(1990): 130-160. DOI: 10.29173/pandp15137.

3. Caap-Ahlgren M, Lannerheim L (2002). Older Swedish women's experiences of living with symptoms related to Parkinson's disease. J Adv Nurs 39(1): 87-95. DOI: 10.1046/j.13652648.2002.02245.x.

4. Charlton GS, Barrow CJ (2002). Coping and self-help group membership in Parkinson's disease: an exploratory qualitative study. Health Soc Care Community 10(6): 472-478. DOI: 10.1046/j.1365-2524.2002.00385.x.

5. Critical Appraisal Skills Programme (2018). CASP qualitative checklist. [online] [cit. 2018-11-19]. Available from: https:// casp-uk.net/wp-content/uploads/2018/01/CASP-QualitativeChecklist-2018.pdf

6. Eatough V, Shaw K (2017). 'I'm worried about getting water in the holes in my head': a phenomenological psychology case study of the experience of undergoing deep brain stimulation surgery for Parkinson's disease. Br J Health Psychol 22(1): 94-109. DOI: 10.1111/bjhp.12219.

7. Eccles FJ, Murray C, Simpson J (2011). Perceptions of cause and control in people with Parkinson's disease. Disabil Rehabil 33(15-16): 1409-1420. DOI: 10.3109/09638288.2010.533241.

8. Gibson G (2016). 'Signposts on the journey'; medication adherence and the lived body in men with Parkinson's disease. Soc Sci Med 152: 27-34. DOI: 10.1016/j. socscimed.2016.01.023.

9. Gibson G, Kierans C (2017). Ageing, masculinity and Parkinson's disease: embodied perspectives. Sociol Healt Illn 39(4): 532-546. DOI: 10.1111/1467-9566.12508.

10. Haahr A, Brincks J, Sørensen, D (2017). Coping with Parkinson's disease in everyday life: a systematic review protocol. JBI Database System Rev Implement Rep 15(5): 1288-1297. DOI: 10.11124/JBISRIR-2016-002989.

11. Haahr A, Kirkevold M, Hall EOC, Østergaard K (2010). From miracle to reconciliation: a hermeneutic phenomenological study exploring the experience of living with Parkinson's disease following deep brain stimulation. Int J Nurs Stud 47(10): 1228-1236. DOI: 10.1016/j.ijnurstu.2010.03.006.

12. Haahr A, Kirkevold M, Hall EOC, Østergaard K (2011). Living with advanced Parkinson's disease: a constant struggle with unpredictability. J Adv Nurs 67(2): 408-417. DOI: 10.1111/j.1365-2648.2010.05459.x.

13. Jacobson N (2012). Dignity and health: a review. Nashville: Vanderbilt University Press.

14. Jonasson SB, Nilsson MH, Lexell J, Carlsson G (2018). Experiences of fear of falling in persons with Parkinson's disease - a qualitative study. BMC Geriatr 18(1): 44. DOI: 10.1186/s12877-018-0735-1.

15. Kalia LV, Lang AE (2015). Parkinson's disease. Lancet 386(9996): 896-912. DOI: 10.1016/S0140-6736(14)61393-3.

16. Korstjens I, Moser A (2017). Series: Practical guidance to qualitative research. Part 2: Context, research questions and designs. Eur J Gen Pract 23(1): 274-279. DOI: 10.1080/13814788.2017.1375090.

17. Liddle J, Phillips J, Gustafsson L, Silburn P (2018). Understanding the lived experiences of Parkinson's disease and deep brain stimulation (DBS) through occupational changes. Aust Occup Ther J 65(1): 45-53. DOI: 10.1111/14401630.12437.

18. Mathers J, Rick C, Jenkinson C, Garside R, Pall H, Mitchell R, et al. (2016). Patients' experiences of deep brain stimulation for Parkinson's disease: a qualitative systematic review and synthesis. BMJ Open 6(6): e011525. DOI: 10.1136/ bmjopen-2016-011525.
19. Matiti MR, Baillie L (2011). Dignity in Healthcare: a practical approach for nurses and midwives. London: Radcliffe Publishing Ltd.

20. McClurg D, Walker K, Aitchison P, Jamieson K, Dickinson L, Paul L, et al. (2016). Abdominal massage for the relief of constipation in people with Parkinson's: a qualitative study. Parkinson's disease 2016: ID 4842090. DOI: 10.1155/2016/4842090.

21. Miller N, Noble E, Jones D, Burn D (2006). Hard to swallow: dysphagia in Parkinson's disease. Age Ageing 35(6): 614-618. DOI: 10.1093/ageing/afl105.

22. Moher D, Liberati A, Tetzlaff J, Altman DG, PRISMA Group (2009). Preferred reporting items for systematic reviews and meta-analyses: The PRISMA Statement. PLoS Med 6(7): e1000097. DOI: 10.1371/journal.pmed.1000097.t001.

23. Nazzal MS, Khalil H (2017). Living with Parkinson's disease: a Jordanian perspective. Scand J Occup Ther 24(1): 74-82. DOI: 10.1080/11038128.2016.1234643.

24. Nordenfelt L (2009). The concept of dignity. Dignity in care for older people. Chichester: Blackwell Publishing Ltd, pp. 26-53.

25. O'Cathain A, Thomas KJ, Drabble SJ, Rudolph A, Goode J, Hewison, J (2014). Maximising the value of combining qualitative research and randomised controlled trials in health research: the QUAlitative Research in Trials (QUART) study a mixed methods study. Health Technol Assess 18(38): 1-197. DOI: $10.3310 /$ hta18380.

26. Olsson M, Nilsson C (2015). Meanings of feeling well among women with Parkinson's disease. Int J Qual Stud Health Wellbeing 10: 28730. DOI: 10.3402/qhw.v10.28730.

27. Pringsheim T, Jette N, Frolkis A, Steeves TDL (2014). The prevalence of Parkinson's disease: a systematic review and meta-analysis. Mov Disord 29(13): 1583-1590. DOI: 10.1002/ mds. 25945

28. Redmond L, Suddick K (2012). The lived experience of freezing in people with Parkinson's: an interpretive phenomenological approach. IJTR19(3): 169-177. DOI: 10.12968/ ijtr.2012.19.3.169.

29. Rod NH, Bordelon Y, Thompson A, Marcotte E, Ritz B (2013). Major life events and development of major depression in Parkinson's disease patients. Eur J Neurol 20(4): 663-670. DOI: 10.1111/ene.12019.

30. Sheehy TL, McDonough MH, Zauber SE (2016). Social comparisons, social support, and self-perceptions in group exercise for people with Parkinson's disease. J Appl Sport Psychol 29(3): 285-303. DOI: $10.1080 / 10413200.2016 .1266711$.

31. Simpson J, McMillan H, Leroi I, Murray CD (2015). Experiences of apathy in people with Parkinson's disease: a qualitative exploration. Disabil Rehabil 37(7): 611-619. DOI: 10.3109/09638288.2014.939771.

32. Smith JA, Flowers P, Larkin M (2012). Interpretative phenomenological analysis. Theory, method and research. London: SAGE Publications Ltd.

33. Smith LJ, Shaw RL (2017). Learning to live with Parkinson's disease in the family unit: an interpretative phenomenological analysis of well-being. Med Health Care Philos 20(1): 13-21. DOI: 10.1007/s11019-016-9716-3.

34. Soleimani MA, Bastani F, Negarandeh R, Greysen R (2016). Perceptions of people living with Parkinson's disease: a qualitative study in Iran. Br J Community Nurs 21(4): 188-195. DOI: 10.12968/bjcn.2016.21.4.188.

35. Soleimani MA, Negarandeh R, Bastani F, Greysen, R (2014). Disrupted social connectedness in people with Parkinson's disease. Br J Community Nurs 19(3): 136-141. DOI: 10.12968/ bjen.2014.19.3.136.

36. Soundy A, Stubbs B, Roskell C (2014). The experience of Parkinson's disease: a systematic review and meta-ethnography. Sci World J 2014: ID 613592. DOI: 10.1155/2014/613592.

37. Stern C, Jordan Z, McArthur A (2014). Developing the review question and inclusion criteria.Am J Nurs 114(4): 53-56. DOI: 10.1097/01.NAJ.0000445689.67800.86.

38. Suddick KM, Chambers S (2010). The lived experience of sleep disturbance in people with Parkinson's disease. J Nurs 
Health Chronic Illn 2(4): 292-301. DOI: 10.1111/j.17529824.2010.01070.x.

39. Sunvisson H (2006). Stopped within a track: embodied experiences of late-stage Parkinson's disease.

Int J Qual Stud Health Well-being 1(2): 91-99. DOI: $10.1080 / 17482620500487547$.

40. Sunvisson H, Ekman SL (2001). Environmental influences on the experiences of people with Parkinson's disease. Nurs Inq 8(1): 41-50. DOI: 10.1046/j.1440-1800.2001.00089.x.

41. Thomas J, Harden A (2008). Methods for the thematic synthesis of qualitative research in systematic reviews. BMC Med Res Methodol 8: 45. DOI: 10.1186/1471-2288-8-45.
42. Turner LM, Liddle J, Pachana NA (2017). Parkinson's disease and driving cessation: a journey influenced by anxiety. Clin Gerontol 40(3): 220-229.

DOI: 10.1080/07317115.2016.1215365.

43. Valcarenghi RV, Alvarez AM, Santos SSC, Siewert JS, Nunes SFL, Tomasi AV (2018). The daily lives of people with Parkinson's disease. Rev Bras Enferm 71(2): 272-279. DOI: 10.1590/00347167-2016-0577. 